\title{
Improvement of Resident Scholarship in an Internal Medicine Training Program
}

J Gen Intern Med 37(1):274-6

DOI: $10.1007 / \mathrm{s} 11606-021-06887-2$

(c) This is a U.S. government work and not under copyright protection in the U.S.; foreign copyright protection may apply 2021

\section{INTRODUCTION}

The Accreditation Council for Graduate Medical Education (ACGME) stipulates that residents must participate in scholarship, and programs must provide curricula to accomplish this. Residents understand that they should participate in scholarly activity, but are often dissatisfied with their program's approach. ${ }^{1}$ Evidence of effective interventions that lead to tangible scholarship in 3-year residencies is inconsistent. Recent systematic reviews have described initiatives utilized by ACGME programs to increase scholarship., ${ }^{2,3}$ Tripler Army Medical Center (TAMC) Internal Medicine (IM) residency program educates a diverse group of civilian and active duty military residents. We initiated simple, reproducible interventions to improve resident participation in and understanding of the medical research process, based on previously published methods. ${ }^{2-6}$

\section{METHODS}

As a process improvement study, a structural framework was developed for scholarly activity within the TAMC IM residency program. A total of 32-39 IM residents per year participated. The interventions took place at the start of the 20162017 academic year. Metrics were collected from July 2016 to June 2019. Metrics from July 2015 to June 2016, before

\footnotetext{
Prior presentations: - American College of Physicians Internal Medicine Meeting, Los Angeles CA, Apr 2020, Winner, Resident/Fellow Research Virtual ePoster Competition

- American College of Physicians Hawaii Chapter Meeting, Honolulu HI, Feb 2020, 3rd Place, Resident Research Poster Competition

- American College of Physicians Army/Air Force Chapter Meeting, San Antonio TX, Sep 2019

Tripler AMC Donald A. Person Poster Session, Honolulu HI, Jun 2019

Received September 292020

Accepted May 3, 2021

Published online June 18, 2021
}

interventions occurred, served as the control. No additional monetary funding was provided.

A Scholarly Activity Council (SAC) was assembled, with a volunteer faculty member serving as Chair (CSAC). The council contained representatives from each IM subspecialty, to act as human resources for projects in their area of expertise. All SAC members were volunteers. The CSAC created a shared access database, including a bulletin of projects needing assistance, deadlines, and a list of project statuses and pending tasks. It was reviewed and updated monthly at a dedicated research conference on the academic schedule, where residents also practiced presentations and discussed projects. Faculty members in attendance at the meeting could give feedback and advice for these presentations or projects. A research curriculum was designed, including monthly lectures on statistical analysis, critical literature appraisal, and guides for manuscript writing. Protected longitudinal research time was added to resident schedules, with 4 weeks of dedicated time per academic year. This time replaced one elective rotation block.

From July 2016 to June 2019, residents were requested to report any new scholarly activity to the Chief of Medical Residents. Metrics collected to evaluate participation included quantity and type of manuscripts published, presentations at local/regional/national conferences, and ongoing or new Institutional Review Board (IRB)-reviewed studies. Abstracts' or manuscripts' pending acceptance and in-house scholarship, such as morning report or grand rounds, were excluded.

\section{RESULTS}

From July 2015 to June 2016, 4 manuscripts and 2 book chapters were published, and 22 presentations were given. This represented the program's baseline scholarly activity. During the 2016-2017 academic year, presentations increased to 45 (Table 1). This increase remained stable, with overall $186 \%$ growth over 3 years. Accepted peer-reviewed manuscripts surged to 8 , and then 14 . This represents a $350 \%$ growth from the initiation of interventions. In June 2016, an 
Table 1 Scholarly Activities by Type, July 2015 to June 2019. Quantities of Posters, Presentations, Book Chapters, Manuscripts Accepted for Publication, and Active IRB Protocols, in Chronological Order. 2015-2016 Refers to the Pre-intervention Academic Year, with the Three Subsequent Columns Representing Academic Years During which Interventions Were Active

\begin{tabular}{|c|c|c|c|c|}
\hline \multirow[b]{2}{*}{ Academic year } & \multirow{2}{*}{$\begin{array}{l}\text { Pre-interventions } \\
2015-2016\end{array}$} & \multicolumn{3}{|c|}{ Intervention period } \\
\hline & & 2016-2017 & $2017-2018$ & 2018-2019 \\
\hline Posters/presentations & 22 & 45 & 39 & 41 \\
\hline Book chapters & 2 & 0 & 1 & 2 \\
\hline Accepted manuscripts & 4 & 3 & 8 & 14 \\
\hline Active IRB protocols & 0 & 3 & 3 & 4 \\
\hline Number residents as first author & 4 & 3 & 8 & 14 \\
\hline Number of residents per year & 32 & 34 & 39 & 39 \\
\hline
\end{tabular}

additional 8 manuscripts were pending acceptance. No active IRB research protocols existed in 2015, but rose to 4 by 2019 .

\section{DISCUSSION}

Scholarship increased within the TAMC IM residency program after instituting reproducible, evidenced-based interventions $^{2-6}$ requiring minimal resources. Overall, the interventions described established a collaborative environment between faculty and residents (Table 2).

Other programs have utilized similar interventions to improve scholarly activity. ${ }^{2-6}$ Among primary care specialties, lack of mentorship and protected time to complete scholarship impacts their ability to fulfill the requirement. ${ }^{4}$ Other factors, e.g., prior research experience and desire for fellowship training, may also affect scholarship. ${ }^{1-4,6}$ Our project presents a standardized, literature-derived approach that is transferable across ACGME programs.

Limitations include a small sample size and limited preintervention data. It is difficult to quantify which aspects of the multi-pronged interventions were most successful, and to what degree the culture change, signaled by an overt focus on scholarship, augmented the individual interventions. We posit that the cumulative effect of the interventions outweighed the sum of their parts.

By developing a stable research environment with designated mentors, we increased our production of peer-reviewed publications. Key to the success of the program was the designation of the CSAC, who was empowered to make substantial, meaningful changes. Further work is needed to evaluate how other specialties may benefit from similar interventions, and to refine further the approach to scholarship across ACGME programs.

Table 2 List of Primary Interventions with Their General Purpose, and Subjective Effects Observed by the Authors Over the Course of the Intervention Period

\begin{tabular}{|c|c|c|}
\hline Interventions & Purpose & Outcome \\
\hline Scholarly Activity & Assemble faculty to act as mentors & Encouraged faculty and resident cooperation and idea sharing \\
\hline Council (SAC) & $\begin{array}{l}\text { Able to assist with scholarship in their subspecialties } \\
\text { Create a standardized review process for manuscript } \\
\text { submissions }\end{array}$ & $\begin{array}{l}\text { Facilitated scholarship dedication and completion } \\
\text { Abstract/manuscript submissions were reviewed by multiple } \\
\text { faculty members }\end{array}$ \\
\hline Chair of Scholarly & Coordinate assembly of the SAC & Changed the culture of the training program \\
\hline Activity (CSAC) & $\begin{array}{l}\text { Lead monthly research meeting } \\
\text { Rotation director for research block } \\
\text { Write and institute research curriculum }\end{array}$ & $\begin{array}{l}\text { Held individuals accountable } \\
\text { Fostered professional relationships and promoted academic } \\
\text { growth }\end{array}$ \\
\hline $\begin{array}{l}\text { Comprehensive shared } \\
\text { scholarship database }\end{array}$ & $\begin{array}{l}\text { Track new/ongoing projects and pending tasks } \\
\text { Introduce residents without experience to process of } \\
\text { scholarly activity in low-risk, public forum } \\
\text { Give residents opportunities to join projects }\end{array}$ & $\begin{array}{l}\text { Changed the culture of the training program } \\
\text { Made scholarship more tangible and accessible for trainees } \\
\text { Encouraged mutual accountability for project tasks }\end{array}$ \\
\hline $\begin{array}{l}\text { Monthly research } \\
\text { meeting }\end{array}$ & $\begin{array}{l}\text { Remind participants of deadlines for projects } \\
\text { Discuss and address barriers to project progression } \\
\text { Allow residents to practice presentations }\end{array}$ & $\begin{array}{l}\text { Changed the culture of the training program } \\
\text { Encouraged mutual accountability }\end{array}$ \\
\hline Scholarship curriculum & $\begin{array}{l}\text { Educate residents in scholarship, including statistical } \\
\text { analysis, critical literature appraisal } \\
\text { Instruct residents in effective manuscript writing by } \\
\text { utilizing multiple staff with publication experience, } \\
\text { specific journals' author instructions, standardized } \\
\text { templates (i.e., cover letters, quality improvement } \\
\text { fishbone designs, etc.) }\end{array}$ & $\begin{array}{l}\text { Improved scholarship quality and quantity } \\
\text { Improved resident understanding of commonly used statistical } \\
\text { methods (correlation, comparison of means, and regression), } \\
\text { study design, study population and size, bias, applicability to } \\
\text { clinical practice, and clarity of original data presentation }\end{array}$ \\
\hline Protected research time & $\begin{array}{l}\text { Grant residents } 4 \text { weeks per academic year dedicated to } \\
\text { scholarship }\end{array}$ & $\begin{array}{l}\text { Increased productivity } \\
\text { Allowed residents to focus on scholarship efforts } \\
\text { Enabled residents to maintain purpose and direction in } \\
\text { long-term projects }\end{array}$ \\
\hline
\end{tabular}


Elizabeth R. Doman, $D O^{1}$

Michael S. Abdo, $M D^{1}$

Dacia S. Boyce, $M D^{2}$

Daniel H. Desmond, $M D^{3}$

Joseph L. Roswarski, $M D^{3}$

David C. Hostler, $\mathrm{MD}^{4}$

${ }^{1}$ Department of Medicine, Tripler Army Medical Center,

1 Jarrett White Road, Honolulu, HI 96859, USA

${ }^{2}$ Katterbach Kaserne,

Ansbach, Germany

${ }^{3}$ Division of Hematology/Oncology, Department of Medicine, Walter Reed National Naval Medical Center,

Bethesda, MD, USA

${ }^{4}$ Womack Army Medical Center, Ft. Bragg, NC, USA

Corresponding Author: Elizabeth R. Doman, DO; Department of Medicine, Tripler Army Medical Center, 1 Jarrett White Road, Honolulu, HI 96859, USA (e-mail: elizabeth.r.doman.mil@mail.mil).

\section{Declarations:}

Conflict of Interest: The authors declare that they do not have a conflict of interest.

Disclaimer: The primary author is a military service member or employee of the US Government. This work was prepared as part of official duties with no additional funding. Title 17, USC. \$105 provides that copyright protection under this title is not available for any work of the US Government. Title 17, USC. \$101 defines a US Government work as work prepared by a military service member or employee of the US Government as part of that person's official duties. The views expressed are solely those of the authors. They do not necessarily reflect the official policy or position of Tripler Army Medical Center, the Department of the Army, the Department of Defense, nor the US Government.
Open Access This article is licensed under a Creative Commons Attribution 4.0 International License, which permits use, sharing, adaptation, distribution and reproduction in any medium or format, as long as you give appropriate credit to the original author(s) and the source, provide a link to the Creative Commons licence, and indicate if changes were made. The images or other third party material in this article are included in the article's Creative Commons licence, unless indicated otherwise in a credit line to the material. If material is not included in the article's Creative Commons licence and your intended use is not permitted by statutory regulation or exceeds the permitted use, you will need to obtain permission directly from the copyright holder. To view a copy of this licence, visit http://creativecommons. org/licenses/by/4.0/.

\section{REFERENCES}

1. Abramson EL, Naifeh MM, Stevenson MD, et al. Scholarly Activity Training During Residency: Are We Hitting the Mark? A National Assessment of Pediatric Residents. Acad Pediatr. 2018;18(5):542-9. doi: https://doi.org/ 10.1016/j.acap.2018.02.002.

2. Stevenson MD, Smigielski EM, Naifeh MM, Abramson EL, Todd C, Li ST. Increasing Scholarly Activity Productivity During Residency: a Systematic Review. Acad Med. 2017;92(2):250-66. doi: https://doi.org/10.1097/acm. 0000000000001169.

3. Wood W, McCollum J, Kukreja P, et al. Graduate Medical Education Scholarly Activities Initiatives: a Systematic Review and Meta-analysis. BMC Med Educ. 2018;18(1). doi: https://doi.org/10.1186/s12909-0181407-8.

4. Becker D. Understanding Faculty and Trainee Needs Related to Scholarly Activity in a Large, Nonuniversity Graduate Medical Education Program, The Permanente Journal. 2017. doi: https://doi.org/10.7812/tpp/16-034.

5. West CP, Halvorsen AJ, McDonald FS. Scholarship During Residency Training: a Controlled Comparison Study. Am J Med. 2011;124(10):9837.e1. doi: https://doi.org/10.1016/j.amjmed.2011.05.018.

6. Ercan-Fang NG, Rockey DC, Dine CJ, Chaudhry S, Arayssi T. Resident Research Experiences in Internal Medicine Residency Programs-a Nationwide Survey. Am J Med. 2017;130(12):1470-6.e3. doi: https://doi.org/ 10.1016/j.amjmed.2017.08.033.

Publisher's Note: Springer Nature remains neutral with regard to jurisdictional claims in published maps and institutional affiliations. 